\title{
Trends in diversity and abundance of obligate epiphytic bryophytes in a highly managed landscape
}

\author{
Alain Vanderpoorten, Patrick Engels and André Sotiaux
}

\begin{abstract}
Vanderpoorten, A., Engels, P. and Sotiaux, A. 2004. Trends in diversity and abundance of obligate epiphytic bryophytes in a highly managed landscape. - Ecography 27: 567-
\end{abstract} 576.

\begin{abstract}
Although forest stands represent $47 \%$ of the total land area in Europe, alterations to the forest habitat through logging and plantation of exotic trees has led to significant changes in forest biocenoses. Due to their peculiar biology and life history, epiphytic bryophytes, which include a number of species of high conservation value, are especially concerned. Ordinal logit regression was used to test whether trends in diversity and abundance of obligate epiphytic bryophytes are explained by forest cover and spruce plantation and determine specific optima and degree of reliance to these factors at the landscape scale. Spruce plantations had a negative impact on both species diversity and abundance. Although large forest patches were important for a set of species exclusively or more frequently occurring under the forest cover, the abundance of a number of species previously identified as woodland bryophytes decreased or was uncorrelated with increasing forest cover. Furthermore, the species pool adapted to edge-related abiotic conditions was important. The global epiphytic diversity did consequently not decrease with decreasing forest cover at the landscape scale. If large forest patches are important for the conservation of a set of species exclusively or more frequently occurring under the forest cover, the conservation of epiphytic bryophytes thus also involves the conservation of pioneer trees in open landscapes. A series of management measures, which may help maximize the species diversity and probability of occurrence of key-species of high conservation interest, are proposed.
\end{abstract}

A.Vanderpoorten (a.vanderpoorten@ulg.ac.be) and A. Sotiaux, Dept of Life Sciences, Univ. of Liège, B-22 Sart Tilman, B-4000 Liège, Belgium. - P. Engels, Dept of Geopedology, Agricultural Fac. of Gembloux, Passage des Déportés, B-5030 Gembloux, Belgium.

Forest and other wooded land cover ca 1000 million ha in Europe, representing $47 \%$ of the total land area (Anon. 2003). Due to fragmentation, logging, and plantation of exotic trees, only ca $1 \%$ of them can, however, be termed as old-growth (Norton 1996). European forests thus mostly range from semi-natural for $2 / 3$ of them to plantations. The latter represent on average $3 \%$ of European woodlands, but this proportion reaches up to $25 \%$ in countries such as Denmark, Belgium, The Netherlands, and Bulgaria (Anon. 2003).

Although protected areas are included as a main pillar in nature conservation laws in all European countries, protected forests, where the conservation of biological diversity and the maintenance of natural ecological processes are the main concern, only include $12 \%$ of European forests. Of these, only $3 \%$ are free of any kind of active intervention, whereas $79 \%$ are still actively managed (Anon. 2003). These differences in levels of utilization are not only characterized by changing structures, but also by a significant decrease of the diversity of many biocenoses in exploited forests at the landscape scale. For example, 1/4 of the total number of forest vascular plants species are endangered in Belgium, Estonia, and Sweden (Anon. 2003). As a consequence,

Accepted 26 March 2004

Copyright (C) ECOGRAPHY 2004

ISSN 0906-7590 
many species are restricted to the last patches of oldgrowth stages (Fuller and Peterken 1995, Graae 2000, Buckley et al. 2002, Thompson et al. 2003) and, alternatively, to old cutting classes in managed forests (Frisvoll and Prestø 1997).

In this context, biodiversity conservation in temperate forest ecosystems has become a major concern (see e.g. Norton 1996). A number of international agreements promoting the sustainable management of forest ecosystems and the conservation of their biodiversity, in particular the EEC directives 79/409 and 92/43, the Ministerial Conference on the Protection of Forest in Europe, and the Convention on Biological Diversity, Decision VI/22 (<http://www.biodiv.org/decisions/ default.asp? $1 \mathrm{~g}=0$ anddec $=\mathrm{VI} / 22>$ ), have been signed.

The parameters defining the conservation value of forest stands are, however, numerous and complex (e.g. tree composition, regeneration mode, and structure, amount of dead wood and overmature trees). Biological indicators are therefore frequently used for assessing the conservation value in such complex ecosystems (e.g. Brehm et al. 2003, Saetersdal et al. 2004, Summerville et al. 2004). In this respect, lichens and bryophytes are especially concerned (Rambo and Muir 1998, Vellak and Paal 1999, Trass et al. 1999). Forest structure indeed determines the local mesoclimate and many hygrophytic species which, as opposed to vascular plants, do not possess any water conducting system and cannot control the loss of water due to their simple morphology (e.g. lack of stomata, unistratose leaf lamina), are extremely drought-sensitive. In addition, many rare bryophyte and lichen species are limited by a low dispersal ability, so that any disturbance of their habitat quickly causes their disappearance due to their low ability to colonize new hosts (Holien 1998, Boudreault et al. 2000, Sillett et al. 2000, Cobb et al. 2001, Berg et al. 2002, Printzen et al. 2002). Furthermore, many epiphytic species are specific to a kind of bark (micro-topography, chemicals exuded) (e.g. Barkman 1958, Bates and Brown 1981). In particular, pioneer softwood trees in mid-western Europe, such as Populus spp., Salix spp., and Sambucus nigra, often exhibit a rich epiphytic flora that differs from that of mature, hardwood stands (Hodgetts 1996, Klein and Vanderpoorten 1997, Vanderpoorten and Engels 2002). As a consequence, the diversity and composition of epiphytic assemblages is linked to a series of forests of different composition, age, and structure. Hence, many cryptogamic epiphytes are very sensitive to forest management practices (Hannerz and Hånell 1997, Newmaster and Bell 2002, Ross-Davis and Frego 2002) and only persist in continuous forest stands including all the stages of the forest cycle (Boudreault et al. 2000, Pipp et al. 2001, McGee and Kimmerer 2002, Ross-Davis and Frego 2002).

Geographical Information Systems (GIS) are an increasingly used tool to integrate the complex informa- tion from different data sets at different geographical scales. More precisely, they can be employed to examine the impact of a series of factors related to local ecological conditions and land use on species distribution to address various issues including conservation actions (Draper et al. 2003). The goals of the present paper are to test whether trends in diversity and abundance of obligate epiphytic bryophytes are explained by forest cover and spruce plantation at the landscape scale. Species response curves are then fitted in order to determine specific optima and degree of reliance to these factors and determine how total forest cover combines with the proportion of exotic trees to explain the observed specific patterns of abundance. Finally, a series of management measures that may help maximize the species diversity and probability of occurrence of key-species of high conservation interest are proposed for the area.

\section{Methods}

\section{Field sampling}

The Semois river basin (Belgium, France) was selected for this study for including large proportion of forest stands. With a proportion of $1 / 3$ of Norway spruce Picea abies plantations and 2/3 of broadleaf forests, woodlands represent $59 \%$ of the total area. Broadleaf forests are mostly represented by stands dominated by Fagus sylvatica and Quercus robur. Other forest types are restricted to specific geomorphological conditions, and include willow fringes along brooks, birch woods (Betula alba) on peaty plateaus, and Acer-dominated stands (Acer pseudoplatanus) on steep slopes. The area was divided into $1104 \times 4 \mathrm{~km}$ squares that served as a basis of comparison between the abundance of obligate epiphytic bryophytes, forest cover and spruce plantation.

Obligate epiphytic bryophytes were defined based on standard lists of reference of bryophyte ecology (e.g. Düll 1992, Dierssen 2001). Almost all species can, however, be very occasionally encountered on other substrate types (e.g. Bates et al. 1997, Vanderpoorten et al. 2001). In addition, species ecology can vary from an area to another. For example, a species such as Orthodontium lineare, which behaves as a genuine epiphyte in Belgium and neighbouring areas, can be found on other substrates in other areas. In total, the data set included 49 species (nomenclature after Sotiaux and Vanderpoorten 2001).

Fifteen years were necessary to complete the field survey by two of us. Field surveys were undertaken during the winter. During that season indeed, the Orthotrichaceae, a diverse family of mostly epiphytic taxa that represented ca $25 \%$ of the whole data set, exhibit ripe capsules. The latter are necessary for species identification in this taxonomically difficult family, 
whose systematics is based on traits such as the location of the stomata on the capsule, their superficial vs immersed position, and peristome architecture. Specimens of these species were systematically collected for subsequent microscopical examination.

In order to assess species abundance, each individual $4 \times 4 \mathrm{~km}$ square was further divided into $161 \times 1 \mathrm{~km}$ sub-squares. Presence/absence of each species was recorded in each sub-square. Because each of the 16 sub-squares was not prospected in an equally intensive way due to different constraints (e.g. the presence of private properties), these frequencies were pooled to obtain a less precise but more robust estimate of species frequency at the scale of the $16 \mathrm{~km}^{2}$ square according to a scale corresponding to $0,1,2-10$, and $>10$ occurrences in the 16 sub-squares. Percent cover of total forest cover and the ratio cover in broadleaf trees/spruce plantation in each $4 \times 4 \mathrm{~km}$ square were measured by a GIS from a digital document (Anon. 1993).

\section{Statistical analyses}

Correlation coefficients between species diversity, forest cover, cover of broadleaf trees, and cover of spruce plantations per $16 \mathrm{~km}^{2}$ square $(\mathrm{n}=110)$ were calculated after graphic inspection of the linearity of the relationship among the variables to apply, if necessary, the appropriate transformation. Species response curves were fitted by ordinal logit regression in order to model the probability of occurrence for each species and each class of abundance. Due to the difficulty to draw conclusions from statistical correlations for rare species, seven species occurring in $<5 \%$ of the $16 \mathrm{~km}^{2}$ gridsquares were omitted from this analysis. Significance of total forest cover $\left(\mathrm{x}_{1}\right)$ and the ratio cover in broadleaf trees/spruce plantation $\left(\mathrm{x}_{2}\right)$ was tested for each species by a $\mathrm{z}$ test, and a backward selection was applied with a significance level to stay in the model of 0.05 . The species probability of occurrence depending on $\mathrm{x}_{1}$ and $\mathrm{x}_{2}$ for each class of abundance ( $i=0,1,2,3)$ were calculated as follows:

$$
\begin{aligned}
\mathrm{p}\left(0 \mid \mathrm{x}_{1}, \mathrm{x}_{2}\right)= & \exp \left(\mathrm{a}_{0}+\mathrm{b}_{1} \mathrm{x}_{1}+\mathrm{b}_{2} \mathrm{x}_{2}\right) / \\
& \left(1+\exp \left(\mathrm{a}_{0}+\mathrm{b}_{1} \mathrm{x}_{1}+\mathrm{b}_{2} \mathrm{x}_{2}\right)\right) \\
\mathrm{p}\left(1 \mid \mathrm{x}_{1}, \mathrm{x}_{2}\right)= & -\mathrm{p}\left(0 \mid \mathrm{x}_{1}, \mathrm{x}_{2}\right)+\exp \left(\mathrm{a}_{1}+\mathrm{b}_{1} \mathrm{x}_{1}+\mathrm{b}_{2} \mathrm{x}_{2}\right) / \\
& \left(1+\exp \left(\mathrm{a}_{1}+\mathrm{b}_{1} \mathrm{x}_{1}+\mathrm{b}_{2} \mathrm{x}_{2}\right)\right) \\
\mathrm{p}\left(2 \mid \mathrm{x}_{1}, \mathrm{x}_{2}\right)= & -\mathrm{p}\left(0 \mid \mathrm{x}_{1}, \mathrm{x}_{2}\right)-\mathrm{p}\left(1 \mid \mathrm{x}_{1}, \mathrm{x}_{2}\right) \\
& +\exp \left(\mathrm{a}_{2}+\mathrm{b}_{1} \mathrm{x}_{1}+\mathrm{b}_{2} \mathrm{x}_{2}\right) / \\
& \left(1+\exp \left(\mathrm{a}_{2}+\mathrm{b}_{1} \mathrm{x}_{1}+\mathrm{b}_{2} \mathrm{x}_{2}\right)\right) \\
\mathrm{p}\left(3 \mid \mathrm{x}_{1}, \mathrm{x}_{2}\right)= & 1-\mathrm{p}\left(0 \mid \mathrm{x}_{1}, \mathrm{x}_{2}\right)-\mathrm{p}\left(1 \mid \mathrm{x}_{1}, \mathrm{x}_{2}\right)-\mathrm{p}\left(2 \mid \mathrm{x}_{1}, \mathrm{x}_{2}\right)
\end{aligned}
$$

The coefficients $a_{1}, b_{1}$, and $b_{2}$ were obtained by the maximum likelihood algorithms implemented by Minitab 13. Square and log transformations of the predictors were tried to improve the fit of the model on the data.
The fit of each model was assessed by pairing the observations with different responses $(0,1,2$, or 3$)$ and calculating the proportion of concordant pairs (CCRs), i.e. the pairs for which the observation with the lowest response level has the lowest predicted event probability.

\section{Results}

Species diversity per grid square averaged 24.0 species, with a minimum and a maximum of 10 and 34 species, respectively. Species diversity was significantly correlated with cover of spruce plantations $(\mathrm{r}=-0.35, \mathrm{p}<0.001)$, but not with cover in broadleaf trees or with total forest cover.

The coefficients of the models fitted by ordinal logit regression to obtain the species probabilities of occurrence at different abundance levels depending on total forest cover and broadleaf/conifer ratio were not significant for 15 species. These included Metzgeria fruticulosa, M. temperata, Bryum laevifilum, Dicranoweisia cirrata, Cryphaea heteromalla, Dicranum tauricum, Leskea polycarpa, Neckera pumila, Orthotrichum affine, O. consimile, O. pallens, O. speciosum, Ulota crispa, $Z y$ godon conoideus, and $Z$. viridissimus. Among the remaining species for which the model coefficients were significant, five different trends were detected depending on total forest cover, broadleaf/conifer ratio, and the combination of both (Table 1a, b): 1) species whose probability of occurrence increased with total forest cover included, in order of increasing demand, Nowellia curvifolia, Antitrichia curtipendula, Metzgeria temperata, Orthodontium lineare, and Lophozia longidens (Fig. 1a); 2) species whose probability of occurrence increased with the broadleaf/conifer ratio included, in order of increasing demand, Radula complanata (Fig. 1b), Metzgeria furcata, and Frullania dilatata; 3) species whose probability of occurrence increased with both total forest cover and broadleaf/conifer ratio included, in order of increasing demand, Ulota bruchii, Zygodon rupestris, Dicranum montanum, Frullania tamarisci, F. fragilifolia, and Microlejeunea ulicina (Fig. 1c); 4) species whose probability of occurrence decreased with total forest cover included, in order of decreasing sensitivity to forest cover, Syntrichia latifolia, S. papillosa, Orthotrichum obtusifolium, O. pumilum (Fig. 1d), Pylaisia polyantha, Orthotrichum stramineum, O. tenellum, and $O$. lyellii; and 5) species whose probability of occurrence decreased with total forest cover but increased with the broadleaf/ conifer ratio included, in order of decreasing sensitivity to forest cover, Platygyrium repens (Fig. 1e), Syntrichia virescens, and Orthotrichum striatum.

Thus, all the investigated species were either uncorrelated or responded positively to an increase of the broadleaf/conifer ratio. Total forest cover, conversely, either led to an increase or a decrease in species 
Table 1a. Values of total forest cover $(\mathrm{T})$ or broadleaf/conifer ratio $(\mathrm{R})$ from which the probability to observe a species at an abundance level of 1,2 , and 3, is 0.5 (single variable models). " - " and "+" indicate that the probability to observe the species with a probability of 0.5 at a given abundance would imply values outside the range of variation of the explaining variable, and indicates if the probability to observe the species is less or greater than 0.5 , respectively. CCR is the proportion of concordant pairs. "/" indicates that the species was never observed at its highest abundance level.

\begin{tabular}{|c|c|c|c|c|}
\hline Species & CCR & $\begin{array}{c}\text { Value from } \\
\text { which } \mathrm{P}(1)=0.5\end{array}$ & $\begin{array}{c}\text { Value from } \\
\text { which } \mathrm{P}(2)=0.5\end{array}$ & $\begin{array}{c}\text { Value from } \\
\text { which } \mathrm{P}(3)=0.5\end{array}$ \\
\hline \multicolumn{5}{|c|}{ Increase in abundance depending on total forest cover $(T)$} \\
\hline Nowellia curvifolia & $63.8 \%$ & $\mathrm{~T}>26 \%$ & - & - \\
\hline Antitrichia curtipendula & $60.7 \%$ & $\mathrm{~T}>85 \%$ & - & - \\
\hline Metzgeria temperata & $66.2 \%$ & $\mathrm{~T}>90 \%$ & - & - \\
\hline Orthodontium lineare & $66.2 \%$ & - & - & - \\
\hline Lophozia longidens & $73.8 \%$ & - & - & - \\
\hline \multicolumn{5}{|c|}{ Decrease in abundance depending on total forest cover $(\mathrm{T})$} \\
\hline Syntrichia latifolia & $61.7 \%$ & - & - & - \\
\hline Syntrichia papillosa & $68.2 \%$ & $\mathrm{~T}<48$ & $\mathrm{~T}<8$ & - \\
\hline Cryphaea heteromalla & $68.8 \%$ & $\mathrm{~T}<40 \%$ & $\mathrm{~T}<16 \%$ & - \\
\hline Orthotrichum obtusifolium & $63.0 \%$ & $\mathrm{~T}<20 \%$ & - & I \\
\hline Orthotrichum pumilum & $70.9 \%$ & $\mathrm{~T}<20 \%$ & $\mathrm{~T}<6.5 \%$ & I \\
\hline Pylaisia polyantha & $75.6 \%$ & $\mathrm{~T}<19 \%$ & $\mathrm{~T}<5.1 \%$ & I \\
\hline Orthotrichum stramineum & $63.5 \%$ & + & $\mathrm{T}<30 \%$ & I \\
\hline Orthotrichum tenellum & $68.6 \%$ & + & $\mathrm{T}<30 \%$ & I \\
\hline Orthotrichum lyellii & $64.6 \%$ & + & + & / \\
\hline \multicolumn{5}{|c|}{ Increase in abundance depending on the broadleaf/conifer ratio $(\mathrm{R})$} \\
\hline Radula complanata & & + & $\mathrm{R}>0.1$ & - \\
\hline Metzgeria furcata & $69.0 \%$ & $\mathrm{R}>0.03$ & $\mathrm{R}>0.03$ & $\mathrm{R}>62$ \\
\hline Frullania dilatata & $63.4 \%$ & $\mathrm{R}>0.08$ & $\mathrm{R}>0.09$ & - \\
\hline
\end{tabular}

abundance, with an intensity depending on the concerned species. For instance, the $50 \%$ chance probability to observe Nowellia curvifolia at its lowest class of abundance was reached for a forest cover of $26 \%$, a value that increased up to $90 \%$ in Metzgeria temperata. Many Orthotrichum species had a $50 \%$ chance probability of occurrence at their lowest class of abundance whatever the forest cover, whereas this probability was reached at a maximum of $48 \%$ in Syntrichia papillosa, the most sensitive species to forest cover in this study. These figures were, however, modulated by the combination of both total forest cover and broadleaf/conifer ratio in certain species. For example, Microlejeunea ulicina, a species favoured by both factors, had a $50 \%$ chance probability of occurrence at its lowest class of abundance for a total forest cover of a least $77 \%$ when the broadleaf/ conifer ratio was 0.1 , but required a total forest cover of only $0.3 \%$ for the same probability of occurrence when the broadleaf/conifer ratio was 100 (Table 1b). On the other hand, Platygyrium repens, a species favoured by a high broadleaf/conifer ratio but decreasing in abundance with forest cover, had a $50 \%$ chance to be observed at its lowest class of abundance when forest cover did not exceed $1 \%$ for a broadleaf/conifer ratio of 0.1 , but tolerated up to $65 \%$ forest cover when the broadleaf/ conifer ratio reached 2 (Table $1 \mathrm{~b}$ ).

\section{Discussion}

About $25 \%$ of the investigated obligate epiphytes had an increasing probability of occurrence with total forest cover. This emphasizes once again the prime importance of forest cover for explaining the distribution of bryophyte species at the landscape scale (Vanderpoorten and Engels 2002). Among the species whose abundance positively correlated with forest cover, Dicranum montanum, Frullania fragilifolia, F. tamarisci, and Zygodon rupestris are well-known examples of ancient woodland bryophytes (Rose 1992, Bates et al. 1997). All of these species exhibit mostly western geographical distribution patterns (Bates et al. 1997). This suggests that such species have a tendency to occur in humid climates with low variation range, and may explain their positive relationships with forest cover, which may provide them with the appropriate buffered mesoclimate.

Paradoxically, a number of other species identified as ancient woodland bryophytes, such as Radula complanata, Orthotrichum lyellii, O. stramineum (Rose 1992) or generally associated with forests, such as Platygyrium repens (Bates et al. 1997), decreased in abundance with increasing forest cover or were not correlated with it. This was true as well for many other epiphytic bryophytes well-known for their tendency to occur in scrub thickets (e.g. Barkman 1958, Hodgetts 1996), including Syntrichia latifolia, S. papillosa, Orthotrichum obtusifolium, O. pumilum, O. tenellum, and Pylaisia polyantha. The tendency of a number of epiphytic species to increase with decreasing forest cover, i.e., to occur in open habitats (forests edges, tree patches, or even isolated trees), explains why the global epiphytic diversity did not decrease with decreasing forest cover at the landscape scale. The preference of rich communities of cryptogamic epiphytes for edges was already documented (e.g. Barkman 1958, Hodgetts 1996, Glavich 2003). This contrasts with the situation encountered in 
Table 1b. Values of total forest cover from which the probability to observe a species at an abundance level L of 1, 2, and 3, is 0.5 given the broadleaf/conifer ratio (two variables models) " - " and "+" indicate that the probability to observe the species with a probability of 0.5 at a given abundance would imply values outside the range of variation of the explaining variable, and indicates if the probability to observe the species is less or greater than 0.5 , respectively. CCR is the proportion of concordant pairs.

\begin{tabular}{|c|c|c|c|c|c|c|c|c|c|c|c|c|}
\hline \multirow[t]{2}{*}{ Species } & \multicolumn{12}{|c|}{ Broadleaf/conifer ratio } \\
\hline & $\mathrm{L}$ & 0.01 & 0.02 & 0.1 & 0.2 & 0.5 & 1 & 2 & 5 & 10 & 50 & 100 \\
\hline \multicolumn{13}{|c|}{ Increase in abundance depending on both total forest cover and broadleaf/conifer ratio } \\
\hline $\begin{array}{l}\text { Ulota bruchii } \\
\text { CCR }=76.5 \%\end{array}$ & $\begin{array}{l}1 \\
2 \\
3\end{array}$ & $\begin{array}{l}+ \\
+ \\
-\end{array}$ & $\begin{array}{l}+ \\
+ \\
-\end{array}$ & $\begin{array}{l}+ \\
+ \\
-\end{array}$ & $\begin{array}{l}+ \\
+ \\
+\end{array}$ & $\begin{array}{l}+ \\
+ \\
-\end{array}$ & $\begin{array}{l}+ \\
+ \\
-\end{array}$ & $\begin{array}{l}+ \\
+ \\
+\end{array}$ & $\begin{array}{l}+ \\
+ \\
-\end{array}$ & $\begin{array}{l}+ \\
+ \\
>85\end{array}$ & $\begin{array}{l}+ \\
+ \\
+\end{array}$ & $\begin{array}{l}+ \\
+ \\
+\end{array}$ \\
\hline $\begin{array}{l}\text { Zygodon rupestris } \\
\text { CCR }=69.8 \%\end{array}$ & $\begin{array}{l}1 \\
2\end{array}$ & $\begin{array}{l}>39 \\
-\end{array}$ & $\begin{array}{l}>39 \\
-\end{array}$ & $\begin{array}{l}>37 \\
-\end{array}$ & $\begin{array}{l}>35 \\
-\end{array}$ & $\begin{array}{l}>28 \\
-\end{array}$ & $\begin{array}{l}>16 \\
-\end{array}$ & + & $+{ }^{+} 22$ & $\begin{array}{l}+ \\
+\end{array}$ & $\begin{array}{l}+ \\
+\end{array}$ & $\begin{array}{l}+ \\
+\end{array}$ \\
\hline $\begin{array}{l}\text { Dicranum montanum } \\
\mathrm{CCR}=73.3 \%\end{array}$ & $\begin{array}{l}1 \\
2 \\
3\end{array}$ & $\begin{array}{l}>90 \\
>90 \\
-\end{array}$ & $\begin{array}{l}>60 \\
>60 \\
-\end{array}$ & $\begin{array}{l}>20 \\
>20 \\
-\end{array}$ & $\begin{array}{l}>13 \\
>13 \\
-\end{array}$ & $\begin{array}{l}>7 \\
>7 \\
-\end{array}$ & $\begin{array}{l}>2 \\
>2 \\
-\end{array}$ & $\begin{array}{l}>1.5 \\
>1.5 \\
-\end{array}$ & $\begin{array}{l}>0.8 \\
>0.8 \\
-\end{array}$ & $\begin{array}{l}>0.1 \\
>0.1 \\
-\end{array}$ & $\begin{array}{l}+ \\
>45 \\
>45\end{array}$ & $\begin{array}{l}+ \\
>28 \\
>28\end{array}$ \\
\hline $\begin{array}{l}\text { Frullania tamarisci } \\
\mathrm{CCR}=77.3 \%\end{array}$ & $\begin{array}{l}1 \\
2\end{array}$ & $\begin{array}{l}100 \\
-\end{array}$ & $\begin{array}{l}>75 \\
-\end{array}$ & $\begin{array}{l}>34 \\
-\end{array}$ & $\begin{array}{l}>25 \\
>100\end{array}$ & $\begin{array}{l}>15 \\
>65\end{array}$ & $\begin{array}{l}>7.5 \\
>35\end{array}$ & $\begin{array}{l}>6 \\
>28\end{array}$ & $\begin{array}{l}>5 \\
>21\end{array}$ & $\begin{array}{l}>3 \\
>15\end{array}$ & $\begin{array}{l}>1 \\
>7\end{array}$ & $\begin{array}{l}>0.4 \\
>5\end{array}$ \\
\hline $\begin{array}{l}\text { Frullania fragilifolia } \\
\mathrm{CCR}=75.3 \%\end{array}$ & $\begin{array}{l}1 \\
2\end{array}$ & $\begin{array}{l}- \\
-\end{array}$ & $\begin{array}{l}- \\
-\end{array}$ & $\begin{array}{l}- \\
-\end{array}$ & $\begin{array}{l}>67 \\
-\end{array}$ & $>34$ & $\begin{array}{l}>12 \\
>50\end{array}$ & $\begin{array}{l}>8.5 \\
>36\end{array}$ & $\begin{array}{l}>5.7 \\
>24\end{array}$ & $\begin{array}{l}>2.7 \\
>14\end{array}$ & $\begin{array}{l}>0.2 \\
>3.8\end{array}$ & $\stackrel{+}{>2}$ \\
\hline $\begin{array}{l}\text { Microlejeunea ulicina } \\
\mathrm{CCR}=79 \%\end{array}$ & $\begin{array}{l}1 \\
2 \\
3\end{array}$ & $\begin{array}{l}- \\
- \\
-\end{array}$ & $\begin{array}{l}- \\
\overline{-}\end{array}$ & $\begin{array}{l}>77 \\
- \\
-\end{array}$ & $\begin{array}{l}>50 \\
- \\
-\end{array}$ & $\begin{array}{l}>29 \\
>77 \\
-\end{array}$ & $\begin{array}{l}>12 \\
>34 \\
-\end{array}$ & $\begin{array}{l}>9 \\
>25 \\
-\end{array}$ & $\begin{array}{l}>6.5 \\
>18 \\
-\end{array}$ & $\begin{array}{l}>3.7 \\
>11 \\
-\end{array}$ & $\begin{array}{l}>0.9 \\
>3.7 \\
>45\end{array}$ & $\begin{array}{l}>0.3 \\
>2.5 \\
>29\end{array}$ \\
\hline \multicolumn{13}{|c|}{ Increase in abundance depending on the broadleaf/conifer ratio and decrease depending on total forest cover } \\
\hline $\begin{array}{l}\text { Orthotrichum striatum } \\
\mathrm{CCR}=72.5 \%\end{array}$ & $\begin{array}{l}1 \\
2\end{array}$ & $\begin{array}{l}<11 \\
<2.5\end{array}$ & $\begin{array}{l}<15 \\
<3.5\end{array}$ & $\begin{array}{l}<29 \\
<8\end{array}$ & $\begin{array}{l}<39 \\
<11\end{array}$ & $\begin{array}{l}<56 \\
<16\end{array}$ & $\begin{array}{l}- \\
<29\end{array}$ & $\begin{array}{l}- \\
<34\end{array}$ & $\begin{array}{l}- \\
<42\end{array}$ & $\begin{array}{l}- \\
<58\end{array}$ & $\begin{array}{l}- \\
-\end{array}$ & $\begin{array}{l}- \\
-\end{array}$ \\
\hline $\begin{array}{l}\text { Platygyrium repens } \\
\mathrm{CCR}=80.7 \%\end{array}$ & $\begin{array}{l}1 \\
2\end{array}$ & $\begin{array}{l}- \\
-\end{array}$ & $\begin{array}{l}- \\
-\end{array}$ & $\begin{array}{l}<1 \\
-\end{array}$ & $\begin{array}{l}<3 \\
-\end{array}$ & $\begin{array}{l}<10 \\
<0.7\end{array}$ & $\begin{array}{l}<41 \\
<6\end{array}$ & $\begin{array}{l}<65 \\
<10\end{array}$ & $\stackrel{+}{<17}$ & $\begin{array}{l}+ \\
<40\end{array}$ & $\begin{array}{l}+ \\
+\end{array}$ & $\begin{array}{l}+ \\
+\end{array}$ \\
\hline
\end{tabular}




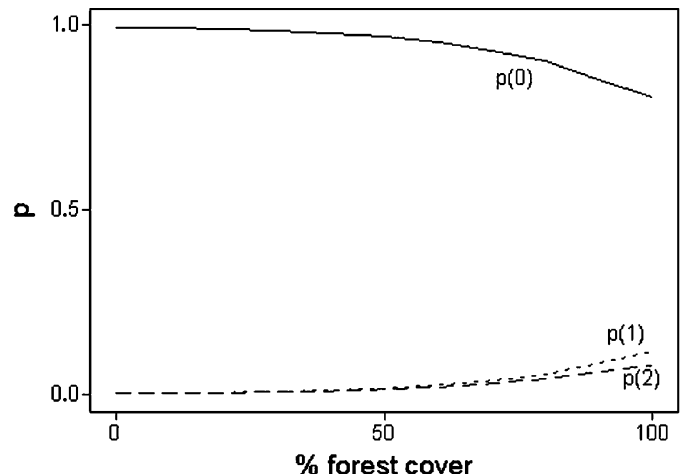

(a)
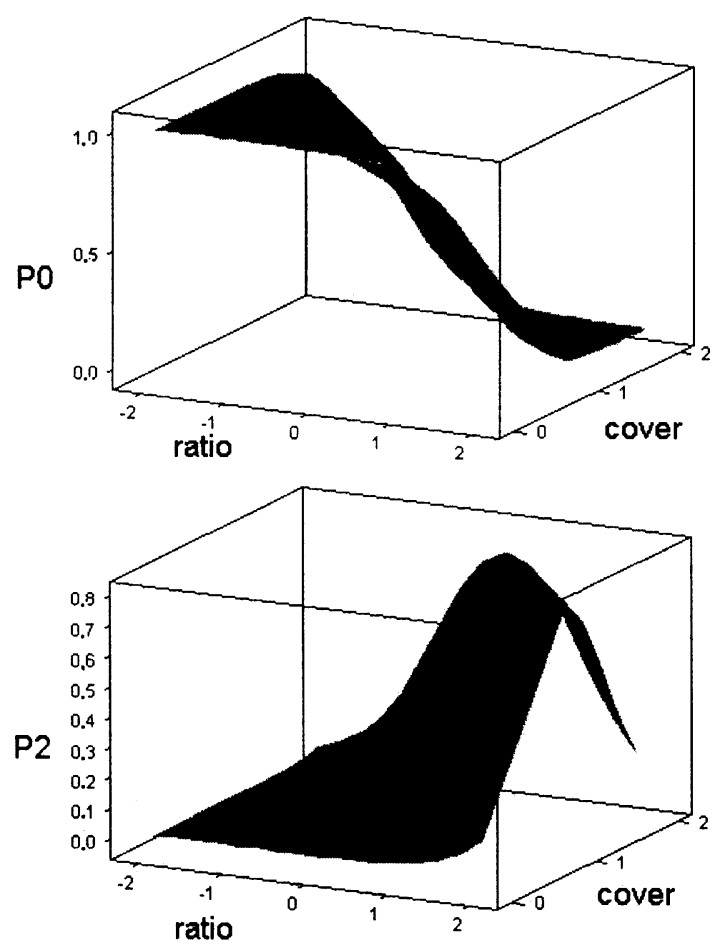

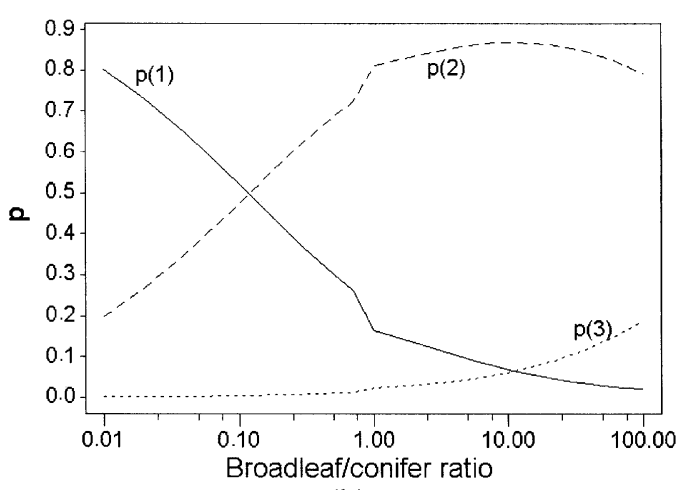

(b)
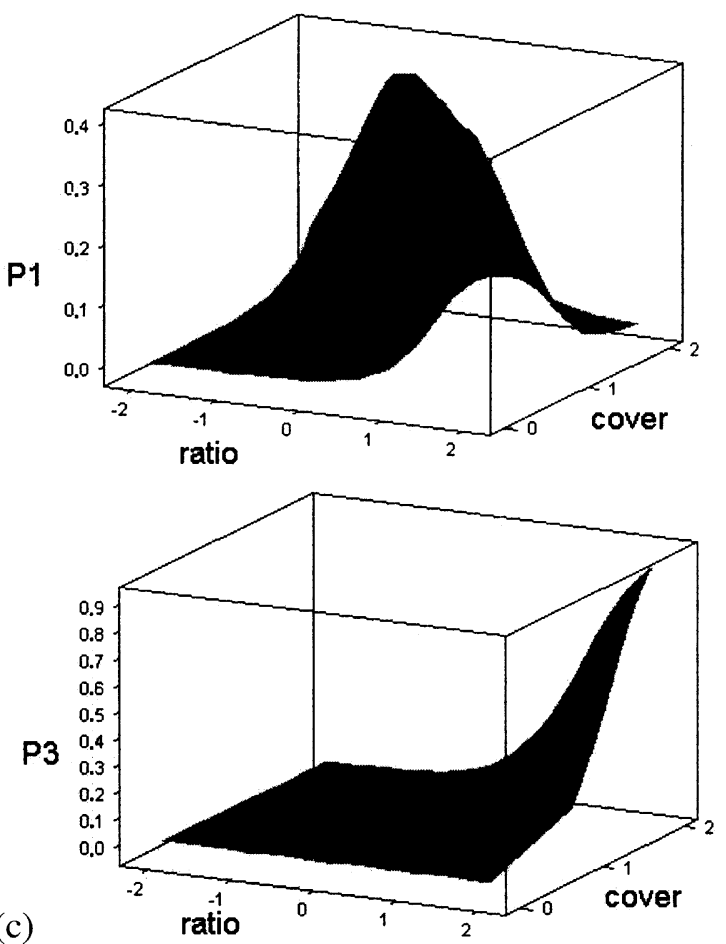

Fig. 1. Species response curves fitted by ordinal logit regression depending on total forest cover, broadleaf /conifer ratio, or a combination of both. a. increase in abundance with increasing total forest cover (Lophozia longidens); b. increase in abundance with increasing broadleaf/conifer ratio (Radula complanata); $\mathrm{c}$. increase in abundance with increasing log-transformed total forest cover and broadleaf/conifer ratio (Microlejeunea ulicina); d. increase in abundance with decreasing total forest cover (Orthotrichum pumilum); e. increase in abundance with log-transformed increasing broadleaf/conifer ratio but decreasing total forest cover (Platygyrium repens). 


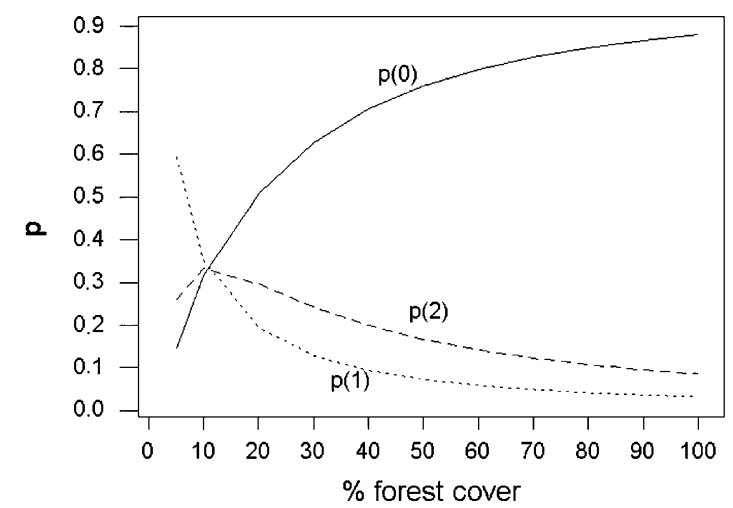

(d)
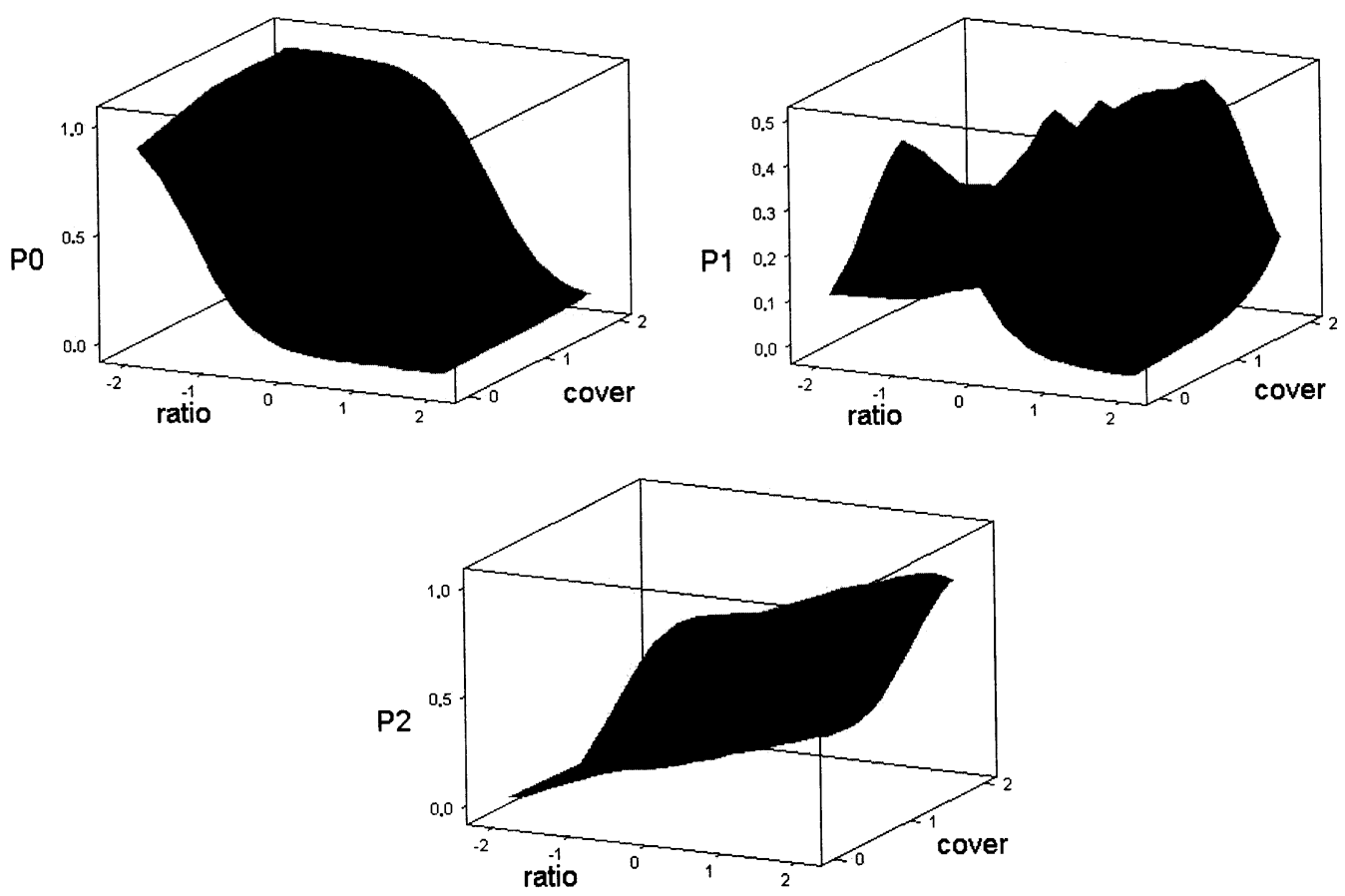

(e)

Fig. 1 (Continued).

angiosperms in the same area, where the diversity and quality of edge communities tend to be much lower as compared to that of the inner forest due to the invasion by a few weedy species (Honnay et al. 2002). The preference for edges observed for many species in the study area also contrasts with observations made on a vast array of other organisms and/or different forest kinds, including lichens (Esseen and Renhorn 1998), insects (e.g. Andresen 2003), birds (e.g. MaldonadoCoelho and Marini 2004), and epiphyllous hepatics of Amazonian forests, for which forest fragmentation clearly alter community structure, resulting in a higher dominance and abundance of a few species compared to continuous forests (Zartman 2003). Apparently, the pool of species adapted to edge-related abiotic conditions, including high wind turbulence, light, rates of evaporation, and ambient temperature, and decreased humidity, is important in the investigated area. One possible explanation for the edge preference of many species in the study area is the fact that ancient European forests would have been open due to the presence of considerable numbers of large grazing and browsing herbivores (Rose 1992). The flora would have, as suggested by Rose (1992), adapted to this partly open environment over a period of perhaps millions of years.

The influence of total forest cover must, however, be interpreted in a qualitative context, as the proportion of spruce plantations, which represent $25 \%$ of the total forest cover in Belgium (Anon. 2003) and is, arguably, the major threat to the indigenous forest, 
also determined the abundance of the epiphytes. No species, even those which, such as Orthodontium lineare and Nowellia curvifolia, are generally considered to be favoured by spruce plantations (e.g. Herben 1994, Stieperaere and Jacques 1995), increased in abundance with increasing spruce cover. Although $O$. lineare has a high rate of invasion resulting from a considerable capacity to colonize all the available substratum at each site thanks to the production of spores (Herben 1994) and relatively desiccation-tolerant protonemata (Duckett et al. 2001), its spread in southern Belgium is fairly recent (Stieperaere and Jacques 1995). As a consequence, the species has not colonized yet all its potential habitats. Nowellia curvifolia is another spreading species which, as opposed to $O$. lineare (Herben 1994), is not limited by substratum availability and displays a large potential of colonization in broadleaf woodland where it mostly occurred in the investigated area.

Furthermore, ca $25 \%$ of the investigated obligate epiphytes decreased in abundance with increasing cover of spruce plantations. The results thus suggest that, at the landscape scale, spruce plantations have a negative impact on both diversity and abundance of epiphytic species. Statistics indicating an increase in forest cover in Europe (Anon. 2003) are therefore irrelevant in terms of conservation if the increase only concerns plantations, as many epiphytes are limited in abundance, whatever the forest cover, if the proportion of broadleaf trees is not sufficient.

These results contrast with those obtained for a range of species from different groups where cover in exotic conifers had a positive impact on native taxa (Humphrey et al. 2000, Jukes et al. 2001). In bryophytes, little work has been published on the potential value of conifer plantations, but a few studies reported apparently contrasting conclusions on the impact of exotic conifers on epiphytes. In a survey on the trunk epiphytes of Fraxinus excelsior, Moe and Botnen (2000) found that the spruce plantation was the most shady habitat having a very sparse epiphytic vegetation, mainly remnants from vegetation established during more open area conditions. By contrast, it is increasingly acknowledged that plantations of exotic tree species can play a role as a substitution habitat for the conservation of rare, native bryophyte species (e.g. Kautz and Gradstein 2001). This is especially true when old-growth stages are achieved (Hodgetts 1996). In particular, Humphrey et al. (2002) found a lack of difference in species-richness values between planted and semi-natural stands. The sitka spruce plots formed a distinctive grouping with the upland oakland plots and shared many characteristic oakwood bryophytes such as Frullania dilatata, $F$. tamarisci, and Lejeunea cavifolia, which were restricted to large patches of broadleaf trees in the present study. Humphrey et al. (2002) thus concluded that factors of long-continuity of woodland cover and a relatively open canopy structure may not be crucial for maintaining bryophyte diversity. A similar case of contrasting ecological requirements was reported in Orthotrichum consimile, which occurs in nearly pristine mountain broadleaf forests in Spain (Mazimpaka et al. 1997). Conversely, the abundance of this species, which mostly occurs on Sambucus nigra, a pioneer, nitrophilous tree characteristic for disturbed places in mid-western Europe (Atkinson and Atkinson 2002), was uncorrelated with either forest cover or broadleaf/conifer ratio in the present study. Such differences in forest species requirements depending on geographic location were already widely noticed in vascular plants (Hermy et al. 1999). In the case of bryophytes, such differences may be due to the strong decrease in host specificity with increasing air humidity (Frahm 1992). This is further corroborated by conflicting observations on host specificity in continental (e.g. Loppi et al. 1999) vs extremely wet areas such as the Pacific Northwest, where epiphytes show no preference for broadleaf or conifer hosts (Peck 1997, Glime and Hong 2002).

This suggests that not the same species can be used everywhere as indicators of forest stands. In the present study, a subset of six species, Ulota bruchii, Zygodon rupestris, Dicranum montanum, Frullania tamarisci, F. fragilifolia, and Microlejeunea ulicina, were indicators, in order of increasing sensitivity, of both forest cover and proportion of spruce plantations. While the $50 \%$ probability of occurrence of Ulota bruchii was reached for the minimal broadleaf/conifer ratio and forest covers at its medium class of abundance, Frullania fragilifolia and Microlejeunea ulicina had a $50 \%$ chance of occurrence at their lowest class of abundance for a broadleaf/conifer ratio of at least $0.1-0.2$ and a forest cover $>65-75 \%$. Except for the least sensitive species Ulota bruchii, which very often bears capsules, and Zygodon rupestris, which produces abundant leaf gemmae, all these species lack efficient dispersal mechanisms (extreme rarity of sporophytes, absence of asexual propagules) and thus meet the requirements of indicators for large, undisturbed forest patches (Norden and Appelqvist 2001).

By contrast, the abundance of many other species with a potential for a high dispersal ability, either thanks to the frequent production of capsules (e.g. Cryphaea heteromalla, Dicranoweisia cirrata, Orthotrichum spp.) or efficient asexual mechanisms of dispersion (e.g. broken leaf apices in Dicranum tauricum, filamentous stem gemmae in Bryum laevifilum), did not correlate to neither forest cover nor broadleaf/conifer ratio. These species, which were present, often in large abundance, in all or nearly all investigated grid-squares, are "colonists" according to life history strategy classification and may thus not display the appropriate features of indicators for forest stands. Furthermore, most of them are currently spreading in western Europe (Bates et al. 
1997, Vanderpoorten and Engels 2002), where they may beneficiate from the low competition in newly available habitats in previously $\mathrm{SO}_{2}$-polluted areas (Bates et al. 1997), or from the spread of nitrophytic bryophyte-rich pioneer phorophytes such as elder, favored by the increase in surface of agricultural wastelands encouraged by recent EEC directives and in agricultural nutrient inputs (Vanderpoorten and Engels 2002).

\section{Implications for management measures favouring epiphytic bryophyte species at the landscape scale}

The results presented here support the idea that, if large, unplanted forest patches are important for the conservation of a set of species exclusively or more frequently occurring under the forest cover, the conservation of epiphytic bryophytes also involves the conservation of isolated, well-illuminated trees that often support a rich, specialized flora. In particular, management measures promoting the design of a minimal intervention area around the trees currently hosting European Red List species such as Orthotrichum consimile, O. rogeri, $O$. scanicum, and Ulota rehmannii (Anon. 1995), may not be appropriate as these species occur on pioneer trees at forest edges or within an open landscape in the investigated area. As these epiphytes must switch from a host to another fairly frequently as their host are pioneer, quite short-living species, the conservation of the epiphytes relies on the conservation and dynamics of regeneration of the phorophytes. The conservation of the epiphytes thus implies that a minimal amount of pioneer trees such as willows and elders are maintained in open habitats such as wet meadows. In those wet meadows managed as nature reserves in particular, the scrub layer is most often cut to favour the vascular flora to the detriment of epiphytic bryophytes, but also of certain other biocenoses (Cattin et al. 2003). This also implies that patches of pioneer trees should be conserved and kept at this dynamical stage to prevent the succession to hardwood stands. This succession indeed threats the conservation of epiphytic bryophytes of high conservation value. For example, van der Pluijm (2001) observed that epiphytic-rich pioneer communities are replaced by mats of a few dominant species when willows reach an age of approximately 20 yr. Appropriate level of disturbance to locally open the landscape may thus be necessary to provide adequate growth conditions to the phorophytes.

Acknowledgements - The senior author is research associate of the Belgian Fund for the Scientific Research (FNRS).

\section{References}

Andresen, E. 2003. Effect of forest fragmentation on dung beetle communities and functional consequences for plant regeneration. - Ecography $26: 87-97$.
Anon. 1993. Plan d'occupation des sols de Wallonie, 1/50 000. Final report. - Namur, Belgium.

Anon. 1995. Red data book of European bryophytes. - Trondheim, (see also internet updates at < http://www.nt. ntnu.no/ soder/ECCB/>).

Anon. 2003. State of Europe's forests 2003. - MCPFE, Vienna. Atkinson, M. D. and Atkinson, E. 2002. Biological flora of the British Isles. Sambucus nigra L. - J. Ecol. 90: 895-923.

Barkman, J. J. 1958. Ecology and phytosociology of cryptogamic epiphytes. - Van Gorcum, Assen.

Bates, J. W. and Brown, D. H. 1981. Epiphyte differentiation between Quercus petraea and Fraxinus excelsior trees in maritime area of southwest England. - Vegetatio 48: 61-70.

Bates, J. W. et al. 1997. Occurrence of epiphytic bryophytes in a 'tetrad' transect across southern Britain 1. Geographical trends in abundance and evidence of recent change. - J. Bryol. 19: 685-714.

Berg, A. et al. 2002. Habitat preferences of red-listed fungi and bryophytes in woodland key habitats in southern Sweden analyses of data from a national survey. - Biodiv. Conserv. 11: $1479-1503$.

Boudreault, C., Gauthier, S. and Bergeron, Y. 2000. Epiphytic lichens and bryophytes on Populus tremuloides along a chronosequence in the southwestern boreal forest of Quebec, Canada. - Bryologist 103: 725-738.

Brehm, G., Sussenbach, D. and Fiedler, K. 2003. Unique elevational diversity patterns of geometrid moths in an Andean montane rainforest. - Ecography 26: 456-466.

Buckley, P., Ito, S. and McLachlan, S. 2002. Temperate woodlands. - In: Perrow, M. R. and Davy, A. J. (eds), Handbook of ecological restoration. Cambridge Univ. Press, pp. 503538.

Cattin, M. F. et al. 2003. The impact of mowing as a management strategy for wet meadows on spider (Araneae) communities. - Biol. Conserv. 113: 179-188.

Cobb, A. R. et al. 2001. Recolonization of bigleaf maple branches by epiphytic bryophytes following experimental disturbance. - Can. J. Bot. 79: 1-8.

Dierssen, K. 2001. Distribution, ecological amplitude and phytosociological characterization of European bryophytes. - Bryophytorum Bibl. 56: 1-289.

Draper, D. et al. 2003. Application of GIS in plant conservation programmes in Portugal. - Biol. Conserv. 113: 337-349.

Duckett, J. G., Goode, J. A. and Matcham, H. W. 2001. Studies of protonemal morphogenesis in mosses. VIII. The gemmiferous protonemata of Orthodontium and Dicranoweisia. - J. Bryol. 23: 181-193.

Düll, R. 1992. Indicator values of mosses and liverworts. - Script. Geobot. 18: 175-214.

Esseen, P. and Renhorn, K. 1998. Edge effects on an epiphytic lichen in fragmented forests. - Conserv. Biol. 12: 13071317.

Frahm, J.-P. 1992. Untersuchungen zur epiphytischen Moosvegetation der Vogesen. - Herzogia 9: 213-228.

Frisvoll, A. A. and Prestø, T. 1997. Spruce forest bryophytes in central Norway and their relationship to environmental factors including modern forestry. - Ecography 20: 3-18.

Fuller, R. J. and Peterken, G. F. 1995. Woodland and scrub. - In: Sutherland, W. J. and Hill, D. A. (eds), Managing habitats for conservation. Cambridge Univ. Press, pp. 329361 .

Glavich, D. A. 2003. The distribution, ecology, and taxonomy of Bryonia spiralifera and B. pseudocapillaris on the Samoa Peninsula, Humboldt Co., coastal northern California. - Bryologist 106: 588-595.

Glime, J. M. and Hong, W. S. 2002. Bole epiphytes on three conifer species from Queen Charlotte Islands, Canada. - Bryologist 105: 451-464.

Graae, B. J. 2000. The effect of landscape fragmentation and forest continuity on forest floor species in two regions of Denmark. - J. Veg. Sci. 11: 881-892. 
Hannerz, M. and Hånell, B. 1997. Effects on the flora in Norway spruce forests following clearcutting and shelterwood cutting. - For. Ecol. Manage. 90: 29-49.

Herben, T. 1994. Local-rate of spreading and patch dynamics of an invasive moss species, Orthodontium lineare. - J. Bryol. 18: $115-125$.

Hermy, M. et al. 1999. An ecological comparison between ancient and other forest plant species of Europe, and the implications for forest conservation. - Biol. Conserv. 91: 922

Hodgetts, N. 1996. The conservation of lower plants in woodland. - Joint Nature Conservation Comm., Peterborough.

Holien, H. 1998. Lichens in spruce forest stands of different successional stages in central Norway with emphasis on diversity and old growth species. - Nova Hedw. 66: 283324.

Honnay, O., Verheyen, K. and Hermy, M. 2002. Permeability of ancient forest edges for weedy plant species invasion. - For. Ecol. Manage. 161: 109-122.

Humphrey, J. W. et al. 2000. The importance of conifer plantations in northern Britain as a habitat for native fungi. - Biol. Conserv. 96: 241-252.

Humphrey, J. W. et al. 2002. Lichens and bryophyte communities of planted and semi-natural forests in Britain: the influence of site type, stand structure and deadwood. - Biol. Conserv. 107: 165-180.

Jukes, M., Peace, A. J. and Ferris, R. 2001. Carabid beetle communities associated with coniferous plantations in Britain: the influence of site type, ground vegetation and stand structure. - For. Ecol. Manage. 148: 271-286.

Kautz, T. and Gradstein, S. R. 2001. On the ecology and conservation of Spruceanthus theobromae (Lejeuneaceae, Hepaticae) from western Ecuador. - Bryologist 104: 607612.

Klein, J.-P. and Vanderpoorten, A. 1997. Bryophytic vegetation in riparian forests: their use in the ecological assessment of the connectivity between the Rhine and its floodplain. - Global Ecol. Biogeogr. 6: 257-265.

Loppi, S., Bonini, I. and De Dominicis, V. 1999. Epiphytic lichens and bryophytes of forest ecosystems in Tuscany (central Italy). - Cryptogamie Mycol. 20: 127-135.

Maldonado-Coelho, M. and Marini, M. A. 2004. Mixed species bird flocks from Brazilian Atlantic forest: the effects of forest fragmentation and seasonality on their size, richness and stability. - Biol. Conserv. 116: 1926.

Mazimpaka, V. et al. 1997. An important area for Orthotrichum consimile Mitt. in Europe: the north-western Iberian Peninsula. - J. Bryol. 19: 832-834.

McGee, G. G. and Kimmerer, R. W. 2002. Forest age and management effects on epiphytic bryophyte communities in Adirondack northern hardwood forests, New York, USA. - Can. J. For. Res. 32: 1562-1576.

Moe, B. and Botnen, A. 2000. Epiphytic vegetation on pollarded trunks of Fraxinus excelsior in four different habitats at Grinde, Leikanger, western Norway. - Plant Ecol. 151: 143-159.

Newmaster, S. G. and Bell, F. W. 2002. The effects of silvicultural disturbances on cryptogam diversity in the boreal-mixedwood forest. - Can. J. For. Res. 32: 38-51.

Norden, B. and Appelqvist, T. 2001. Conceptual problems of ecological continuity and its bioindicators. - Biodiv. Conserv. 10: 779-791.
Norton, T. W. 1996. Conservation of biological diversity in temperate and boreal forest ecosystems. - For. Ecol. Manage. 85: 1-7.

Peck, J. E. 1997. The association of commercially harvestable bryophytes and their host species in northwestern Oregon. - Bryologist 100: 383-393.

Pipp, A. K., Henderson, C. and Callaway, R. M. 2001. Effects of forest age and forest structure on epiphytic lichen biomass and diversity in a douglas-fir forest. - Northwest Sci. 75: $12-24$.

Printzen, C. et al. 2002. New and interesting lichen records from old-growth forest stands in the German National Park Bayerischer Wald. - Nova Hedw. 74: 25-49.

Rambo, T. R. and Muir, P. S. 1998. Bryophyte species associations with coarse woody debris and stand ages in Oregon. - Bryologist 101: 366-376.

Rose, F. 1992. Temperate forest management: its effect on bryophyte and lichen floras and habitats. - In: Bates, J. W. and Farmer, A. M. (eds), Bryophytes and lichens in a changing environment. Clarendon Press, pp. 211-233.

Ross-Davis, A. L. and Frego, K. A. 2002. Comparison of plantations and naturally regenerated clearcuts in the Acadian forest: forest floor bryophyte community and habitat features. - Can. J. Bot. 80: 21-33.

Saetersdal, M. et al. 2004. Vascular plants as a surrogate species group in complementary site selection for bryophytes, macrolichens, spiders, carabids, staphylinids, snails, and wood living polyporous fungi in a northern forest. - Biol. Conserv. 115: $21-31$.

Sillett, S. C. et al. 2000. Four years of epiphyte colonization in Douglas-fir forest canopies. - Bryologist 103: 661-669.

Sotiaux, A. and Vanderpoorten, A. 2001. Check-list of the bryophytes of Belgium. - Belg. J. Bot. 134: 97-120.

Stieperaere, H. and Jacques, E. 1995. The spread of Orthodontium lineare and Campylopus introflexus in Belgium. - Belg. J. Bot. 128: 117-123

Summerville, K. S., Ritter, L. M. and Crist, T. O. 2004. Forest moth taxa as indicators of lepidopteran richness and habitat disturbance: a preliminary assessment. - Biol. Conserv. 116: 9-18.

Thompson, I. D., Baker, J. A. and Ter-Mikaelian, M. A. 2003. Review of the long-term effects of post-harvest silviculture on vertebrate wildlife, and predictive models, with an emphasis on boreal forests in Ontario, Canada. - For. Ecol. Manage. 177: 441-469.

Trass, H., Vellak, K. and Ingerpuu, N. 1999. Floristical and ecological properties for identifying of primeval forests in Estonia. - Ann. Bot. Fenn. 6: 67-80.

Van der Pluijm, A. 2001. Orthotrichum acuminatum H. Philib., a Mediterranan moss new to The Netherlands. - Lindbergia 26: $111-114$.

Vanderpoorten, A. and Engels, P. 2002. The effects of environmental variation on bryophytes at a regional scale. - Ecography 25: 513-522.

Vanderpoorten, A., Sotiaux, A. and Sotiaux, O. 2001. Integrating bryophytes into a forest management plan: lessons from grid-mapping in the forest of Soignes. - Cryptogamie Bryol. 22: $217-230$.

Vellak, K. and Paal, J. 1999. Diversity of bryophyte vegetation in some forest types in Estonia: a comparison of old unmanaged and managed forests. - Biodiv. Conserv. 8: $1595-1620$.

Zartman, C. E. 2003. Habitat fragmentation impacts on epiphyllous bryophyte communities in central Amazonia. - Ecology 84: 948-954. 